Copyright (C) 2017 by Academic Publishing House Researcher

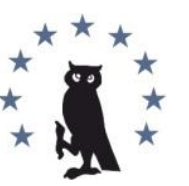

Published in the Russian Federation

European Researcher. Series A

Has been issued since 2010.

ISSN 2219-8229

E-ISSN 2224-0136

2017, 8(2): 48-57

DOI: 10.13187/er.2017.2.48

www.erjournal.ru

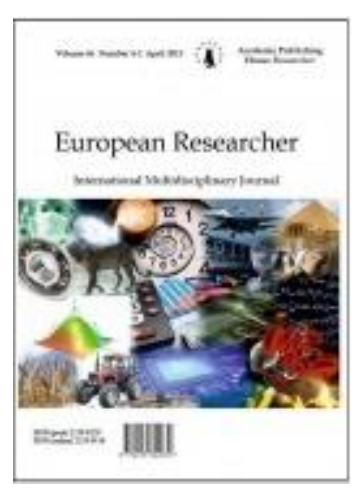

UDC 39

\title{
Natural Places of Worship of Khwarezm, connected with Water Elements
}

\author{
Zaynab K. Abidova ${ }^{a}$, * \\ a Urgench State University, Urgench, the Republic of Uzbekistan
}

\begin{abstract}
This article is devoted to studying of natural places of a pilgrimage connected with the water cult elements of Khwarezm. The remnants of ancient religions are studied and analyzed, rites that are connected with water traced in the Khorezm oasis. Special attention is paid to the history of studying of genesis and evolution of a cult of water of the Khorezm hagiology and their roles in life of inhabitants of the Khorezm oasis which are an important step on the way of revival of spiritual and cultural life of the Uzbek people. The scientific works and the works of authors among which the main place is taken by domestic and foreign ethnographers are analyzed in a chronological order, at the same time the author's researches are used on the field.

Keywords: water, cult, places of a pilgrimage, legend, ceremony, Hubbi, Amu Darya. Corresponding author

\section{Introduction}

Each people aim to learn the past, the got historical heritage and unforgettable pages of the left times and to be proud of great events of the history and his heroic persons. Various social, economic and political events in the region were closely connected with large historical and cultural changes, various state and ethnic associations which exerted huge impact on the world processes and been catalysts of emergence. Also various social and historical and cultural processes are closely connected with antique Khorezm about what many archaeological and ethnographic data witness (Dzhabbarov, 2014). Khorezm* - the most ancient cultural oasis located in lower reaches of the deep Amu Darya River and between the deserts in the north of Uzbekistan. Khorezm is considered as one of the centers of the most ancient civilization. Khorezm is bordered from the North with the sea, from the East and the southwest with the Kara-Kum and Kyzyl-Kum Deserts (Mankovskaya, Bulatova, 1978).
\end{abstract}

\section{Relevance}

The object of study is the system of the natural places of worship remaining today in life of Muslims of the Khorezm oasis. The territory of the Khorezm oasis was from time immemorial rich

\footnotetext{
${ }^{*}$ Corresponding author

E-mail addresses: zaynab_74_2011@mail.ru (Z.K. Abidova)

* Our article covers a wider area than the modern geographical concept of "Khorezm region" includes the territory of the Republic of Karakalpakstan and Turkmenistan, which were part of ancient Khorezm and Khiva Khanate
} 
with the holy sites to which believers worshipped. Many of these place having magic power remained till today, attracting the pilgrims wishing to be part of high spirit of Saints or to get rid of various illnesses and diseases. Natural places of worship of Khorezm didn't arise spontaneously, and it was created during thousands of yearsin the history of its people. Khorezm was the trade intersection of the great Silk Route from the South to the North and from the West to the East from time immemorial. Routes of development of Khorezm along which both cultural values and the related prototypes of a conduct of life extended can be considered as the peculiar "power lines"in many respects determining specifics of a cultural landscape of this area including sacral. For many centuries "The Great Silk Route" passed through the Khorezm oasis trade ways from China to Europe and back. Respectively, this region was the meeting place of the different people and cultures. Strengthening of interest in studying of sacral places of worship of Uzbekistan is caused not only increase in interest in a history of religion certainly. Presently much attention is paid to a subject of sacral space, especially studying of natural places of worship in world science, and especially in Uzbekistan where in Soviet period this sphere actually wasn't studied. Now the whole world realizes that, so far as the topic concerns spiritual culture, it begins not with objects, not with artifacts, and with the ideas, and with the sacral spaces which are given rise by these ideas. For this reason for updating of vital force we consult to the cradle of our ancestors, to sacral places a perennial spring of force, the place of familiarizing to sacred.

\section{Materials and methods}

Lately around the world great concern is caused by environmental problems, careful attitude to the nature, and rational use of its resources. Availability of cult places and the religious prohibitions integrated to them helps though relatively to keep the nature in original state as a life source. At the same time in Uzbekistan noticeable rise in the field of development of the ethnographic, ecological and religious tourism is observed which is directed to use of sacral objects initially. Describing the structure of sacral space the French philosopher Levi-Bryul wrote: "The sacred place never acts in consciousness as something separate or isolated. Every time it is an element of wider complex where the certain types of plants and animals abounding in this place during certain periods enter; mythical heroes who lived here created, dwelt - the heroes who are quite often merged with this the soil, embodied in this area, at last, the feelings which are woken up by this mythological complex" (Sacred space...).

Studying the esteemed objects the ethnographer V.L. Ogudin has allocated six functions which these objects perform for the population living in the territory adjoining to them: consolidating, mediator, communicative, tire-tread, medical and nature protection (Ogudin, 2003). And, the same object can correspond to the one of the listed several functions or even all at once.

\section{Discussion}

Honoring of natural objects in Khorezm isn't so strongly expressed in comparison with other areas of Central Asia. But in life of the people of the oasis located in the lower reaches of the deep Amu Darya River which are between the Kara-Kum and Kyzyl-Kum Deserts, water holds a specific place and it caused the interest in studying of this phenomenon.

There is saying in Khorezm and it is very much appreciated "There is no life without water, there is no pleasure without effort". Because the life of the people of the Khorezm oasis which are engaged in agriculture as well as in some other regions of the Ancient East depended first of all on existence of water sources and artificial irrigation (Dzhabbarov, 1968). Geographical and cultural and economic conditions of the Khorezm oasis promoted that the central place in religious beliefs, since the most ancient times, was occupied by a cult of water elements which to be between deserts. It was reflected in beliefs of the Khorezm oasis and could receive independent value in the developed pantheons the images of goddesses of fertility representing water elements.

According to ancient representations, the basis of the universe was made by four sacred elements - the earth, water, air and fire. Water was esteemed as one of sources and a life basis. In Avesta there is a deity of water elements and the rivers Ardvisura - Anakhita to whom the special anthem is devoted (Avesta, 1990). The people of Khwarezm living between deserts considered water sacred and tried to keep waters of the rivers, channels and wells to purity. The concept of special sacral purity of water elements is shown in those ritual measures with what tried to protect or exempt water from all pollution, well of course it is impossible to tell channels 
and reservoirs in the sanitary relation were in an ideal order earlier. But there were moments when the whole ritual of purification of water in the well, flowing, or standing in reservoirs was required. It occurred when in water for any of several reasons there was a dead body of the person, the dog or other animal occurs (Snesarev, 1969). People of an oasis held off those "impure" people and pets at least 15 meters far from water (Field..., №1).

As well as in all Central Asia and in Khorezm there are "sacred" rivers, channels, sources, wells and hauza (pool) which are usually located about mazars (funerals) meet. According to a number of the field researches carried out by us, one may say that very many of these funerals; sanctuaries arose about water sources (Field..., №2).

Sacred rivers. All know that water of the Amu Darya River was of great importance for the life of the Khorezm oasis located between deserts. Ancient Greek authors called Amu Darya "Oksus" or "Oks", and the Arab writers by "Zhaykhun". As there would be no Egypt without the Nile, also there would be no Khorezm without the Amu Darya. As the famous geographer and the historian of the Middle Ages al Istakhri writes, Khorezm is the country which has managed to receive all advantage of Zhaykhun wholly (Dzhabbarov, 2014). Oasis is the true creation of Amu Darya (Mankovskaya, Bulatova, 1978). The wellbeing of the Khorezm population is closely connected with the river and is therefore the Amu Darya was the subject to worship. There were a gratitude for life-giving force, and fear of blind destructive elements of the 'mad' river. The vital river has a rich and interesting story, its manifestations are shrouded in a crape of written legends and fairy tales, it is sung in songs and national poems. The awful and whimsical nature of the Amu Darya became the reason of emergence of various national myths and legends. One of the widespread legends connected with deyish (washing off of the coast) is a legend of spiteful spirits. According to the legend, the evil and faceless ghosts of an aranglar (idea of their plurality is characteristic) live in the depth of the Amu Darya and control its flow. They can change a watercourse willingly, create deyish, the wash away coast, heat the ships, create a flood, and destroy the cities and villages (Dzhabbarov, 2014).

However in representations about the aranglar (ghosts) also the opposite relation to them is traced. In Muslim interpretation and in many information it is said that they "bring benefit to people" and "the beings loved by god". Aranglar are these invisible, shades inhabit all around the world. They appear in the desert, but also in these beliefs they don't lose some touch with elements of water: "... if the person gets lost in the desert and is parched with thirst, aranglar give him water to drink to" (Snesarev, 1969). Different superstitions, traditions, and customs appeared on the basis of similar legends. For example, followed those traditions the ships began to install the legendary symbols on a nasal part of the ship going across the Amu Darya.

Hubbi's cult was the patron of water of the Amu Darya. In the Khorezm hagiology it holds a specific place, and is traced in traditions of honoring of the water elements. Studying the history of an irrigation of ancient Khorezm the academician Ya.G.Gulyamov, has written down a number of the legends connected with the Amu Darya by old residents. Very curious legend of Hubbi - the young man of the patron of the river tells the old boatman: "Long before Ferydoon and even Dzhemshid (Guliamov, 1957) on this river there lived a young man who became the master of the river. His name was Hubbi, he ate fish: having caught fish from water, he held it up to the sun, and fish fried. During seven hundred years while he was on Amu Darya, there was no any evil ghost and even mosquitoes in and on the river. In Jamsheed's reign Hubbi has disappeared (Guliamov, 1957). They believed that he was kidnapped by the Beauty, the ruler of the heavenly seas. After his disappearance on the Amu-Darya, Hubbi's mother, Ardvisura-Anakhita, has appeared, she looked for the son with crying for a long time. She both has built the first boat and has trained people in navigation to war at water. Thousand years she held mourning, together with her weight the world even the underground demons cried. Then Hubbi's mother has disappeared forever. According to the stories that earlier on a nose of courts by informers, the torso of the woman was represented. When Muslims came there, they cut down a face of a figurine. Since then at this figure the face is cut down and there were only two braids" (Guliamov, 1957).

Mother of the patron of waters Hubbi, Ardvisury-Anakhita ("Great mother", "The goddess mother" (Woman, 1992)) was the cult of fertility, the goddess of waters, representing the great water highway of Central Asia, the ancient Oks (the Amu Darya) (Snesarev, 1969). The women of Khorezm worshipped Anakhita as the Saint, the patroness of fertility of the most popular in oasis. They approached the river, did a sacrifice where there was a boat which has her figurine of 
Anakhita (Field..., №3). The Amu-Darya was especially attractive for barren women. Among people there is a belief to sacral supernatural forces of the Amu-Darya taking the central place in traditions and ceremonies extended among barren women (Snesarev, 1969). Stories of old boatmen are in this regard very interesting which vessels childless women in the past elected the place for holding the ceremonies connected with the Amu-Darya (Snesarev, 1969). Old dargha (a helmsman) told the vessel of the Amu Darya: "When a boat (vessel) was at the coast, childless women rose by it and three times bypassed around a mast and beams which are sticking out in the boat, touching them. The helmsman gave them a patiya (blessing) and received flat cakes and scarfs; childless women, hoping to give birth in the future to the child, drank the water which has accumulated at the bottom of the vessel" (Snesarev, 1969; Field..., №4).

However the main objective of the barren women was to get into a front-tip part of the vessel what boat-masters in every possible way interfered with. This results from the fact that the place in the vessel about its front tip was considered forbidden, or tabooed. In this place usually there was only a helmsman. On this part of the vessel it was strictly forbidden to hit by something, it was even impossible to go into that place which adjoins a nose without the permission of the helmsman. The sailors who were usually working at the vessel without trousers were obliged to put on them when they needed to approach to the front tip part of the vessel. The matter is that this place of the vessel was devoted, according to myths, to their feast patron to Saint Noah (in "The Bible"). However the original reasons of it lie much more deeply. The Amu Darya vessels differed in one feature: their nasal part (a basha), by old tradition, was made out an original image. It was given the form of the human head, in the center the mirror was located, from its sides two long braids weaved out of the horsehair overhung. Here they beat small cloves a piece of a velvet with the coins sewed on it, and amulets. "The boat nose resembled the human head very much." The story-teller says: "When the vessel turned, it seemed that someone was turning the head". According to some facts the nose of the vessel represented Saint Noah's head - a feast of vessels (the patron of boatmen). Most part says that special decoration of a 'head' didn't matter especially. Such explanation is the result of dying off of religious representations in general. However others take place, the interpretation of this phenomenon from generation to generation transferred, namely: that a nose of the vessel represent the head the Ambar-ona (Snesarev, 1969) (mother ArdisuryAnakhita under the influence of Islam of the goddess of fertility in ancient Khorezm the image a sacred Ambar-ona "took shape") (Gorshunova, 2007). Among women there is a ceremony at which barren women, having agreed with boatmen or fishermen, crossed a watercourse, moving to other coast of Amu-Darya, throwing sacrificial salt and bread into her waters and calling the patroness Ambar-ona and took a patiya (blessing) from ticket collectors of the ferry. Were often transported by small boats as was considered that what will swing stronger on the Amu-Darya's waves, the ceremony will be that her action. Such magic crossings through the Amu-Darya were made in the most various points. Especially crossings about Pitnyak (higher than Hazarasp) were famous where on a small island was available the tomb for Arandzha-bobo. Moving through the Amu-Darya, women made ziyarat(pilgrimage) on the island, binding matter rags on a banner of a mazar(grave)and vowing in case of childbirth to sacrifice a ram (Field...№5). Among women it was widespread legends of stay on this island of children's souls, allegedly from time to time shown to people.

In other cases the woman simplified a ceremony: they just came to the Amu-Darya coast and, without being transported on other coast, made sacrifices to her waters, throwing into them grain flat-cakes and salt. Possibly, at least sacral actions known in Khorezm, when childless women stepped or jumped through aryk(irrigation ditch) with the current water, were the facilitated option of the same ceremony. Usually it was made in the spring when new water of the Amu-Darya arrived to the canals of an oasis, and also was followed by a sacrifice to water (Snesarev, 1969).

In ethnographic materials of Khorezm, including folklore, any bright mythological image didn't remain to idolize the Amu-Darya. Here the domination of Moslem was too old. Therefore it is necessary to address the ceremonial party of the Khorezm beliefs again to find any traces of this ancient cult. Ceremonies in which it is sometimes obvious is sometimes more hidden, the AmuDarya acts as the central object of a cult, and are quite numerous (Snesarev, 1969). Among the people the belief saying is widespread that the person passes allegedly infernal tortures menacing to him according to the Islamic rule and if he/she crosses the Amu-Darya current seven times. Despite Muslim coloring, this belief goes back to an ancient cult of the Amu-Darya (Snesarev, 1969). Most brightly honoring of waters of the Amu-Darya is noticeable in ceremonies of a 
sacrificial cult which differed in a variety and was made in the most various occasions. It is quite natural that such ceremonies, first of all, took place in that environment which had the closest contact with the Amu-Darya. For example, the boatmen are drivers of the Amu Darya vessels whom all life passed on the river and on channels. The least difficult, but the sacrifice ceremony of salt to the Amu-Darya water was very widespread. The boatmen made it during sails to avoidance allegedly of "evil eye". The boatmen made also bloody sacrifices to the Amu-Darya. Before the next departure, after loading of the vessel, they brought a ram or other small cattle on it and cut it, lowering blood in the Amu-Darya water (Field..., №6). By traditions the boatmen, during descent to water the new vessel for the first time to the Amu-Darya, they threw the darga (the helmsman) into water (symbolically). This ceremony is similar to that which was observed in case of start-up of the Amu Darya water to canals in this case, they threw the mirab (the water distributor) into water (symbolically). Difficultly with all reliability to establish roots of this custom is that there is a basis to believe that dropping of a darg or mirab into the water are some very late transformation of a ceremony of a sacrifice (Snesarev, 1969). The solemn church services made in Khiva at the beginning of XX in before the floods of the Amu Darya were an echo of ancient beliefs also. As Ya.G. Gulyamov reports that the Muslim clergy organized a solemn procession to the island Aralcha-Auliya located on the lowered part of Tuya-muyun. There gathered all nobility of an oasis with gifts and sacrificial bulls.

Upon termination of a prayer theythrew the killed bull into the river as the victim to patron spirit of the rivers. There are legends that the Khivan governor Allakulikhan $(1825-1842)$ at startup of water through Tash-saka who is again constructed head constructions and has made a sacrifice of a bull. The terrible and mercy Amu Darya was both a creator and the destructor of life and prosperity of the country and its inhabitants (Mankovskaya, Bulatova, 1978).

In the past there were many ceremonies of propitiation of the Amu-Darya at which the victim was the livestock, in particular a bull or a ram. These ceremonies were a consequence of a number of representations sacral ceremonies of water elements, cult value of the Amu-Darya and her concern with the idea of fertility. A special role of a sacrificial animal - a bull, tracing deep roots back to the area the totemic beliefs, later closely connected with magic of growth of the plants and with water which are going back to different stages in the history of religious beliefs (Snesarev, 1969).

With the distribution of Islamic religion there were new stumps connected by Muslim ideology at the historical arena. The patron of waters of the Amu Darya Hubbi has turned in as historical Sultan Hubbi (Hubbi Hodge) the personality has entered hagiographical literature of Khorezm (Guliamov, 1957). The goddess of water and fertility Ardisuva-Anakhita has turned in protecting the sacred woman the Ambar-ona. On legends Sultan Hubbi was the son of the popular, Khorezm sheikh Hakeem ata(Suleyman Bakirgani), Anbar-ona was his wife whose second marriage was with other sheikh of Zengi-ata, is known on all average in Central Asia as the patron of shepherds (Snesarev, 1969). The legend about Hakeem-Ata and Ambar-ona is very popular among the population of Khorezm. However not the official Muslim version, but numerous national legends represent the most popular image of Ambar-ona as the Saint patronesses of women in the oasis (Snesarev, 1969).

There are very numerous legends about Hakeem-ata and his wife Ambar-ona and their sons and have a number of options. A legend was about Hakeem-ata, the historical person and one of the sheikhs and propagators of Islam. The Sufi sheikh was the mystic and the wonder-worker, married to the beautiful daughter of Burakhan, Ambar-ona having three sons: Askar, Mahmood and Hubbi (Sultan Ubbi, Hubbi-hodzha, Hubbi,). The senior and the second were their father's favorite sons; the youngest was Ambar-ona's favorite. At test for obedience, Hubbi was late and he was at home only on the third call of mother, then it became clear that Hubbi was on the AmuDarya saved the perishing vessel, made a miracle, saved the water recovering the killed bulls who were sacrificed to him. This event brought to the culmination the old conflict between Hakeem-ata and the youngest son, and he would tell that Hubbi should leave the house. Hubbi was going to leave. Mother locked him in the room, but he, having thrown off clothes, turning into a pigeon, departed from the window of the house.

After that he disappears completely therefore he is considered by the people as Goyib-bobo (disappeared granddad). During field studies Khorezm we found that in the region there are more than 50 places of pilgrimage associated with the name and Hubbi Goyib Bobo (who escaped). In Xonqa district, in the village of Durgadyke, Khorezm region have called the name of Mazar 
Sulton Hubbi and the local population believe his disappearance place. (Field..., №7; Snesarev, 1969). By other version of a legend he has plunged together with a bullock cart and horses into depth of waters of the Amu Darya, was considered that he is alive and there will come time when he appears again (Snesarev, 1983).

In Hanka (a district of Khorezm region) option after transformation into a pigeon Sultan Hubbi appeared in the village of Durgadyk. The legend says: "Near Hubbi's house the tree grew, a bird has flied to it and everything around was visible from top of the tree. The bird has told that "It is the good place, beautiful; it is possible to live here". According to the legend, Sultan Hubbi was a bird pigeon, for a while stopped in this place. At that moment Anbar-ona, Hubbi's mother was drying the wheat under the tree. The pigeon pecked the wheat, and mother, without having recognized the son, has banished him, and he has told: "Don't banish me with stones, your eyes will be filled with tears" and with these words he has filed away". Hubbi in the form of a pigeon gives the idea of soul of the dead. As the object of honoring though has disappeared, but he is alive" (Mankovskaya, Bulatova, 1978). On legends Hubbi disappears in the Amu-Darya's waters where he becomes some kind of lord of the underwater world.He regulates the mode of the river, feeding the Khorezm oasis, entering fight against the spirits causing floods of undercurrents, the aranglara (Dzhabbarov, 2014).

The informant from Khanka, forty six years who has worked on the Amu Darya vessels tells: "The help is given to the vessels by Sultan Hubbi on the river. When there is a disaster in the vessel, helmsmen address him, and he helps. The seamen did sacrifices to Sultan Hubbi and other Saints. On legends during the natural disasters, at floods when it filled in the villages, he, Sultan Hubbi fought against aranglar and spoke to them: "Clean water!" and underwater spirits submitted to him (Guliamov, 1957).

Sultan Hubbi had very interesting predecessors, ideas of whom were kept by the ethnography of Central Asia. Their images go back genetically to much earlier stage of an embodiment of water elements. Such is water spirit of Sochli-ata ("the hairy father"). The owner of the underwater world, grazing fish herds, it is Hubbi's image, and he was a feast patron fishery drawn in beliefs of the Uzbeks in Khorezm. But the feast of fishers in Khorezm unlike many other patrons has distinctly kept ancient pre-Muslim lines: this is not the patron saint, but the mythical living being dwelling in the water and grazing herds of fishes there (Snesarev, 1969).

With water elements the image of Hubbi that has disappeared and the mourned deity, is associated as the important link binding the image of Hubbi with images of the classical dying and reviving deities.

D. Freyser who convincingly proved connections of these images with the nature, with the flora almost didn't disclose motive of the water in this complex though it is distinctly traced in the myths and ceremonies devoted to Osiris, Tammuz, Adonis and other companions of Great goddesses researched by him (Snesarev, 1969).

Channels. The economy of Khorezm, both in the past, and in the present is impossible without mechanical irrigation. The economy determined the corresponding form in the field of ideology, in this case in the field of hagiology: the man-made channels taking water from Amu Darya purchased patrons on behalf of a number of the Khorezm Saints. Already thousands of years many channels of Khorezm contain once ideas of deities and spirits that were connected with their waters, and they were replaced by Muslim Saints.

Especially respectful relation existed to the water arriving on channels on fields of Khorezm since ancient times. Here it is necessary to pay attention to one, in our opinion, very essential phenomenon (Snesarev, 1969). Almost all main channels of Khorezm playing a large role in economic life of an oasis are connected with a name of this or that Saint. Such Saint was sometimes esteemed as the patron of the channel, and sometimes was called as its direct founder, by wonderful method removed water from Amu-Darya.

As classical example in this case the Saint Palvan-ata (Pahlavan Mahmoud) - the national hero, the wrestler and the poet (Snesarev, 1983), the patron of Khiva who allegedly created the main channel wonderfully which received his name after respectively. This version was created contrary to paradoxical temporary discrepancy: the legend was widely adopted not earlier than the $14^{\text {th }}$ century when there lived historically quite real "Saint", the patron of Khiva, in many centuries after the valid construction of the channel. The legend of the cartridge of the city of Khiva Palvanata which, passing from the coast of the Amu-Darya towards Khiva, drew the staff on the ground is 
especially widespread, and after it, the line stretched after him and the ready channel called by the name of Palvan-ata (Snesarev, 1983).

Precedents to a legend of Pakhlavan Mahmoud speak about sacral communication of Saints with water. Almost similar legend about wonderful burrow through of the channel is connected with a name of the Saint sheikh Husim-bobo from Hazarasp(district in Khorezm) who the staff dewatered a part from Palvan-yab channel. Vicinities Taxta (the city in Turkmenistan) were flooded allegedly through channel by Khan-yab Saint Ismamut-ata* (Snesarev, 1983) (Isim, the son Musaiba), funeral yard which it was read in this area on ruins of the ancient settlement carrying the name Eshrat-kala (the city in Turkmenistan). Saint Suleyman (Tomb near the village Madir, Xonqa district) was considered as the patron of linkage of channels to the south of Khanka, the prayers were organized at his grave when there was not enough water in channels. There was a proverb "If ask water, ask from Suleyman!" (Field..., №7). Shabbaz-bobo (Field..., №8) channel was on the right coast of the Amu-Darya as the bearer of water on fields, the funeral tombwhich was about Kyat as the breakup was esteemed (town Biruniy). The linkage of channels near Gurlen has resulted from the "miracles" made by local Saints (Snesarev, 1983).

Among people the legend about the channel Gaziabad* (Snesarev, 1983) (who would leak through Kushkupyr district is widespread which is connected with evil spirits of Aranga. The legend says that once the Amu Darya had risen so that it flooded the coast of the Gaziabad channel and the village's withtheir crops. According to the legend, this situation was connected with the fact that Aranga(evil spirits) were angry with people and have declared a war against them. The people were in panic and didn't know what to do. One leading mullah who realized all complexity of situation has taken a sword and has climbed down the mountain directly to the river. When he went into the awful raging waves, people waited for what would occur further, and suddenly water in the channel calmed down and began to flow quietly. But the water reddened, and on a surface emerged the blood-stained body of a patron mullah. On a legend, water in the channel has calmed down as a result of fight between ishan (patron of mullahs) and Aranga. Being considered as the evil forces directed against people, Arangi not always won, sometimes they were powerless in front of the mind and insight of the human being. This channel was named after Gaziabad in honor of a heroic act of the ishan (Dzhabbarov, 2014).

Hauz (Pools), sources and lakes. At Islam reign, having in many respects, the former cult of water lost the initial value and gained the nature of superstition. Sacred sources, hauza and lakes are the embodiment of purity and virtue therefore the visitors have to come with good intentions here that after worshiping they should find forces for overcoming hostility and offenses. Water drink from sources, attachment of rags of fabric to branches of surrounding trees (tying the Alam) in the honor of a funerals and in pursuance of the desires make an important part of a ceremony of a pilgrimage to the holy sites. The pilgrim, besides the put ceremonial actions, makes on the holy site simple physiotherapeutic procedures (drink of mineral water, bathing, lying in hot sand, etc.) doing thereby, for contagious magic.

Hauz (Pool). One of the most esteemed places of ancient Khorezm, a tomb Uvays Karany (SultonVais-bobo), Sultan-Uiz Mountains which was at the foot of mountains in the Biruniy district of the Republic of Karakalpakstan. Sultan Vais-bobo, was popular among the people as the healer and the patron of guides of camels. In tomb of Sulton Uvays there is the sacred big by the sizes hauz - (pool) surrounded with pilgrims. The water in it was considered "sacred". It was drunk, washed with it a face, and very many made full ablution. "Holy water" was taken away in cans and bottles.

The miracle pool was tried to be coordinated nevertheless to the Saint, and the legend that fresh spring water follows from legs of the buried Saint was framed (Snesarev, 1969; Field...№9). Also the ritual is bound and performed by the pilgrims, generally childless people, at the sacred tomb with the hauz. They go from the pool barefooted on the stones and prickles along a dry bed or Soy according to which excess of water of the hauz flows down in the spring only. On the road they tie pledging rags on scrubs or rocky prominences. The banks of the soy (pool) are speckled by

\footnotetext{
${ }^{*}$ Isym lived at the time of the Prophet Muhammad, and his father-Musaib gases became famous as a commander, "Army of Islam", participating in many battles for the Muslim faith.

${ }^{*}$ Gazi in the past - the fighters for the faith, and later - just died a violent death. [6. P. 44]
} 
gullies and clefts between rocks, the pilgrims bypass them, and squeeze through them. At the end of the way they build of several stones "the arvokh uyi"(house of spirit), lodges of ancestors, smalltype imitations of inhabited constructions, a symbolical sign of magic communication with a sanctuary. It is considered that this ritual helps to get rid of sterility and other female diseases (Field..., №9).

Sacred fishes live in the sacred pool there. They live in transparent water. To feed fishes and even to look at them was considered as charitable and curative deed. These fishes competed with Sultan-bobo in popularity. Local people spoke about terrible punishments by illness or even the instant death of those who attempted upon the life of sacred fishes (Field..., №9). These behavior shows the cult of fish in system of a zoolatry in Khorezm. Bulaq (a groove) flowing breaking through the earth goes from Sultan Uvay's grave. Bulak is closed strongly otherwise too much water will go from it. The water flows down from the pool, the gorge and there" (Holy Places...). There is another sacred hauz like this in near the tomb of Yusuf Hamadany, in the village of Beshmergan, the Shavat district of Khorezm region.

Mineral and medical sources, lakes. Three types of the target pilgrimage to places of worship are observed in Khorezm: Sufi - for finding of spiritual guidance of the Saint, traditional and Muslim - for finding of merits before Allah and national, for finding of the help and protection of the Saint. One of the important purposes of a pilgrimage in local Islam is visit of shrines with the medical purposes.

There are several underground, mineral and medical sources in Khorezm on geographical position. For example, near Hazarasp to be salty spring "Sulton Sanzhar Mozy", "Kiranch Eshon Bobo" in center of sandy lands of Yangiarik district, there is a salty spring as "Ok Machit" and 'Korazhik' and "Palvan-ata". Near Khiva which is a source of the hydrochloric water. From abovementioned we can say that these sources and springs are medical and are widely used by scientific medicine for prophylaxis and treatment of various diseases. From ancient times the people of Khorezm and the neighboring regions of the republics came to the sources, bathed to the hydrochloric water, used salts, dug their body in the sands. By means of these sources radiculitis, a rheumatic disease and any ulcers of a body treated. People considered these recoveries "karomat" (commission of miracles) of Saints, sources and springs considered as "sacred" and it became the reason of emergence of various national myths and legends. The bulak (the groove) "Palvan-ata" is near to Khiva 3-4 km from in the southern part of the city. If one digs out the earth through 12 meters, there will be water which has in structure a set of chemical elements, having medicinal properties. If patients with a rheumatic disease and illnesses of a nervous system bathe in the spring, they feel on easier. People arriving here consider to be treated that the spring arose with assistance of "karomat" (commission of miracles) of Palvan-ata. Therefore who looks for the help from the Saint, at first does sacrifices (a ram or a goat) or alms to spirit Palvan-ata and recite prayers, allegedly then he would help the sick person to recover (Rakhmanov, Yusupov, 1963). Since 1960 the water of the spring began to decrease gradually. The rumors began to spread among people that all agedly Palvan-ata "was angry" because his mausoleum was turned into the museum and therefore the water in the spring decreased (Rakhmanov, Yusupov, 1963). In 1960 near the spring there began the work of digging the main collector "Big lake" in order to improve the ameliorative conditions of the irrigated lands of Khorezm, that was the main reason for decreasing of water in the spring (Field...№10). Such sources exist in the village of Serchali in Khiva district and in sands of Kushkupyr and Shavat district.

Salty mine the Sulton Sanzhar Mozy (with $30 \mathrm{~km}$ length and $10 \mathrm{~km}$ width) is located in the south of Khorezm. The mine is bound to a name of the sultan of Seldzhuk Sulton Sandzhar (11181157). The legend is bound to him, it says that, Sultan Sandzhar referred the Amudariya current to Kara-Kum, and as a result of it there were hydrochloric mines and sands appeared. By other option of a legend that in sands there were lakes when the prophet Ibrahim celebrated a wedding on these places, on his "favor" there were salts which were medicinal for people (Rakhmanov, Yusupov, 1963). This mine provided the people of the Khorezm oasis with edible salt for many years. It was used to treat rheumatologic patients when built the Tuya-muyun water-reservoir engineering system (the $80^{\text {th }}$ years of the $20^{\text {th }}$ centuries), the main part of the mine remained under the reservoir. The Hazarasp district in the territories of Kara-Kum there is one more saline mine "Kiranch Eshon bobo" with well-known history. Its creation was considered as the miracles created 
by Kiranch Eshon-bobo. The Salt and dirt of this mine helps to treat illnesses of nervous, cardiovascular systems, and digestive tract (Field..., №11).

The salt mine "Ok Machit" is in the Yangiarik district. The mine is very rich in salts of high concentration and alimentary. Since ancient times the people of Khorezm extracted from the mine alimentary salt, and among the people it received the name "cheap". The mine is medical and therefore always was the focus of attention, medicinal properties of the mine considered as sacred for "Saint" Kozi Umar (Shaykh Mukhtor Valy's father) whose tomb was near the mine in Yangiarik district.

"Making of miracles" by Saints became the reason of emergence of various national myths and legends. For example, among people there are beliefs about Govukkol (lake) near Khiva that from this the lake was taken the clay for construction of Kabah-tullah (Mecca-Medina) and on it became larger in size and more medical. They say that when this lake dries up, then there will be a doomsday. If anybody from Khiva goes to Mecca-Medina to a hajj, the local people there allegedly ask them whether "Is there water on the lake, isn't it dried yet?". All this is final the myth, but actually, composition of the water in the lake Govukkul is rich with minerals (Rakhmanov, Yusupov, 1963). The medical composition of minerals helps to treat pains in legs, radiculitis and different ulcer diseases (Rakhmanov, Yusupov, 1963). According to historical data at first the amount water of the lake was smallreally. People used the clay from the lake for the construction of houses and the handicraftsmen in the purpose of preparing products. There are some facts that for the construction of the walls of Dishan-kala, in 1841 the clay was taken from Govukkul Lake, and so gradually the amount of the lake began to extend (Field..., №12).

Wells. There were esteemed wells in very many places attracting, first of all childless women in Khorezm, usually about funeral places. For example, there is a well near to the tomb of Shakhimardan in Khiva district. According to informants, childless women did a pilgrimage to the tomb, "bent over the well and depending on the fact that in the water it was reflected the moon or stars that judged the one who at them shall be born, the boy or the girl" (Field..., №13). Guessing, as we were convinced of it on a number of examples, is already the latest transformation of a ceremony from the point of view of primitive psychology in whichquite real, in our opinion, communication of sacral qualities of heavenly bodies and a child-bearing, undoubtedly, and serves as another proof of the fact that honoring of heavenly bodies took the important place in a fertility stump (Snesarev, 1983).

The mausoleum of Pahlavon Mahmoud (Palvan-ata) is in the city of Khiva, in the central part of Ichan-Kala. The tomb of the Saint attracted pilgrims from every quarter of the Republic. There were women and men of all age coming to the mausoleum: old men joined sanctity of this place, the women carried theirsick children or went on purpose "to implore" the child, brides on the eve of the wedding dropped to the tomb threshold, asking blessing for marriage. Pakhlavon Mahmoud mausoleum has a well which is considered as sacred, everyone coming to the Saint surely drinks water from a well and take away it in bottles, regarding the water curative. Especially newlyweds cometo the mausoleum, before their wedding and ask Palvan-ata for blessing on marriage and that they would have many children ask. There is such a sign, saying a prayer, the groom shall throw a bucket into a well when it rises, on the water in a bucket they guess who at them to be born the first, the boy or the girl. On a sign if the bucket is complete, it is meant by the boy and if the girl is incomplete (Field..., №13).

\section{Conclusion}

In conclusion it is possible to repeat once again: neither the person, nor society is inconceivable without the idea of sacral, both in individual consciousness, and in collective unconscious. Studying of sacral geography moves us to the answer to the main world outlook issue: whether overcoming the nature is the unique vector of development of a civilization? The tradition of consideration of the nature as means of achievement of social, economic or political goals threatens with degeneration not only the nature, but also the person and his future.

Thus, higher and higher the stated materials gives the grounds to claim that elements of ancient water cult elements as a component entered the religious practice of the people of the Khorezm oasis. Honoring of natural places and Saints of whom people ask for help and protection, the legends connected with mysterious places of their rest is an inseparable part of traditional culture of the Khorezm people. It is connecting the past and the presentas well the thread. 


\section{References}

Dzhabbarov, 2014 - Dzhabbarov Isa (2014). Ancient Khorezm - a country of high culture and a unique spirituality (Ethno-historical essays). Moscow, $304 \mathrm{p}$.

Mankovskaya, Bulatova, 1978 - Mankovskaya L.Yu, Bulatova V.A. (1978). Monuments Khorezm architecture. Tashkent, $192 \mathrm{p}$.

Dzhabbarov, 1968 - Dzhabbarov Isa (1968). Secrets of ancient ruins. Tashkent, $188 \mathrm{p}$.

Avesta, 1990 - Avesta (1990). Selected Hymns. Translation from Avesta an and comments of prof. I.M. Steblin-Kamensky. Dushanbe, 176 p.

Snesarev, 1969 - Snesarev G.P. (1969). Relics of pre-Islamic beliefs and practices in Khorezm Uzbeks. Moscow, 369 p.

Snesarev, 1983 - Snesarev G.P. (1983). Khorezm legends as a source on the history of religious cults of Central Asia. Moscow, 213 p.

Rakhmanov, Yusupov, 1963 - Rakhmanov A, Yusupov S. (1963). "Holy" places in Khorezm and their origin. Tashkent, $29 \mathrm{p}$.

Guliamov, 1957 - Guliamov Ya.G. (1957). History of Khorezm irrigation. From ancient times to the present day. Ans. Ed. Acad. S.P.Tolstov. Tashkent. 313 p.

Woman, 1992 - Woman in myths and legends. Under O.P. Valyanskaya edition. Encyclopedic Dictionary. Tashkent, 1992. 192 p.

Ogudin, 2003 - Ogudin V.L. (2003). Natural places of worship in the religious ideas of the modern population of Fergana. Abstract diss. ... Doctor. historical. Sciences. Moscow. 52 p.

Gorshunova, 2007 - Gorshunova O.V. (2007). Female deities in the system of religious and philosophical ideas of the peoples of Central Asia Author. dis ... Doctor historical Sciences. Moscow. 50 p.

Holy Places... - Holy Places of Khorezm and Karakalpakstan. Yusupov A. [Electronic resource]. URL: http://www.centrasia.ru. (Accessed: 18.01.17).

Sacred space... - Shubnitsina E.I. Sacred space and contemporary nature of the Urals. [Electronic resource]. URL:http://www.pandia.ru/ (Accessed: 22.12.16).

\section{Field data of the author}

Field..., №1 - Field data of the author №1. Khorezm region.Urgench district, village Karaul, an informant Tukhta Makhmudova. March 2016.

Field..., №2 - Field data of the author №2. Khorezm region. Khiva, Khazarasp, Xonqa district. 2015-2016 year.

Field..., №3 - Field data of the author №3. Khorezm region. Khazarasp district, village Pitnyak, Inf. Ruzmetova Oybibi, in December 2016.

Field..., №4 - Field data of the author №4. Khorezm region. Xonqa District, village Tomadurgadik, Inf. Vafaev Bobojon. September 2016.

Field...№5 - Field data of the author №5. Khazarasp district, village Yangibazar, Pitnyak, in august 2015 .

Field...№6 - F ield data of the author №6. Urgench district, village Cholish, in april 2016.

Field..., №7 - Field data of the author №7. Xonqa district, village Durgadik and Madir, in october 2016. March 2016

Field..., №8 - Field data of the author №8 The tomb in the town of Beruni, Karakalpakstan.

Field...№9 - Field data of the author №9. Beruni district of Karakalpakstan, the tomb Sulton Uwais. May 2016.

Field..., №10 - Field data of the author Yangiarik district. Village Ok machit, in may 2016. 2016 .

Field..., №11 - Field data of the author №10. Khazarasp district, village Pitnyak, in march

Field..., №12 - Field data of the author №12. Khiva district, Lake Govukkul, village Badirhan in september 2016.

Field..., №13 - Field data of the author №13. Khiva town, Ichan-kala mausoleum Pakhlavan Mahmoud, in september 2016. 